\title{
ANATOMICAL STUDY OF THE POSTEROLATERAL LIGAMENT COMPLEX OF THE KNEE: LCL AND POPLITEUS TENDON
}

\section{ESTUDO ANATÔMICO DO COMPLEXO LIGAMENTAR POSTEROLATERAL DO JOELHO: LCL E TENDÃO POPLÍTEO}

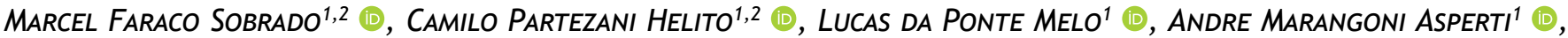 \\ RICCARDO GOMES GOBBI ${ }^{1}$ [1], FABIO JANSON ANGELINI ${ }^{1}$ (1)
}

1. Hospital das Clínicas da Faculdade de Medicina da Universidade de São Paulo, São Paulo, SP, Brazil.

2. Hospital Sírio Libanês, São Paulo, SP, Brazil.

\section{ABSTRACT}

Objective: To analyse the distances between the femoral insertions of the popliteus tendon (PT) and the lateral collateral ligament (LCL) through dissections of cadaveric specimens in a mixed population. Methods: Fresh cadavers were dissected, and the anthropometric data of all specimens were recorded. The distances from the origin of the PT to the LCL in the femoral region and the diameter of each structure were measured using a digital calliper. Results: In total, 11 unpaired knees were dissected, eight men and three women, with an average age of $71.5 \pm 15.2$ years, weight of $57.2 \pm 15.6 \mathrm{~kg}$, and a mean height of $170.5 \pm 8.2 \mathrm{~cm}$. The distance from the center of the femoral footprint of the LCL to the PT was $10.0 \pm 2.4 \mathrm{~mm}$. The distances between the edges closest to each other and those more distant from each other were $3.1 \pm 1.1 \mathrm{~mm}$ and $16.3 \pm 2.4 \mathrm{~mm}$, respectively. Conclusion: The distance between the midpoints of the PT and the LCL in our mixed population is smaller than the distances often reported in the literature. PLC reconstruction with separate tunnels for the LCL and PT may not be technically possible for individuals of any population. Level of Evidence III, Diagnostic studies.

Keywords: Knee. Knee Dislocation. Tendons. Knee Injuries.

\section{RESUMO}

Objetivo: Analisar as distâncias entre as inserções femorais do tendão poplíteo (TP) e o ligamento colateral lateral (LCL) através de dissecções de espécimes cadavéricos em uma população miscigenada. Métodos: Cadáveres frescos foram dissecados. Foram registrados dados antropométricos e foi avaliada a distância da origem do TP e do LCL na região femoral com auxílio de paquímetro digital. Foi também avaliado o diâmetro do footprint femoral do TP e do LCL. Resultados: Foram dissecados 11 joelhos não pareados, 8 homens e 3 mulheres com uma idade média de 71,5 \pm 15,2 anos, pesando em média 57,2 \pm 15,6 kgs e com altura de 170,5 $\pm 8,2 \mathrm{~cm}$. A distância do centro do footprint femoral do LCL e do TP foi de 10,0 $\pm 2,4 \mathrm{~mm}$. As distâncias das bordas mais próximas entre si e das mais distantes entre si foram de 3,1 $\pm 1,1 \mathrm{~mm}$ e 16,3 $\pm 2,4 \mathrm{~mm}$, respectivamente. Conclusão: $A$ distância entre o ponto central do TP e do LCL em nossa população mais miscigenada demonstrou um valor absoluto menor do que é, frequentemente, relatado na literatura. Uma reconstrução ligamentar do CPL com túneis separados para o LCL e o TP pode não ser tecnicamente possível para indivíduos de qualquer população. Nível de Evidência III, Estudos diagnósticos.

Descritores: Joelho. Luxação do Joelho. Tendões. Traumatismos do Joelho.

Citation: Sobrado MF, Helito CP, Melo LP, Asperti AM, Gobbi RG, Angelini FJ. Anatomical study of the posterolateral ligament complex of the knee: Icl and popliteus tendon. Acta Ortop Bras. [online]. 2021;29(5):249-252. Available from URL: http://www.scielo.br/aob.

\section{INTRODUCTION}

Once considered rare, lesions of the posterolateral ligament complex (PLC) may be present in up to $16 \%$ of knee ligament injuries. ${ }^{1}$ Non-recognition of these lesions and their inadequate treatment are associated with residual instability and failure in reconstruction of the anterior and posterior cruciate ligaments. ${ }^{2,3}$ Knowledge about the anatomy and biomechanics of the knee PLC has increased in recent years. Adequate identification of anatomical structures is essential for correct treatment of ligament injuries of the knee. Existing reconstruction techniques are diverse and classified as anatomical or non-anatomical. ${ }^{4-6}$ Some of these techniques do not include reconstruction of the popliteus tendon (PT), although recent studies have shown the biomechanical importance of the PT and the popliteofibular ligament to the posterolateral stability of the knee.,8 As a result, surgeons tend to use surgical techniques that reproduce the anatomical insertions of the structures, especially the insertions of the PT and the lateral collateral ligament (LCL) in the femur.

All authors declare no potential conflict of interest related to this article.

The study was conducted at the Institute of Orthopedics and Traumatology of Hospital das Clínicas of the Medical School of Universidade de São Paulo. Correspondence: Marcel F. Sobrado. Rua Dr. Ovídio Pires de Campos, 333, São Paulo, SP, Brazil, 05403010. marcel.sobrado@usp.br 
To construct the femoral tunnels of the LCL and PT, some authors recommend constructing two separate tunnels, whereas others prefer using a single femoral tunnel from which the two structures originate..$^{5,7,9-11}$ One of the main studies on the anatomy of the PLC of the knee found a mean distance of $18.5 \mathrm{~mm}(16.8-22.9 \mathrm{~mm})$ between the midpoint of the normal anatomical insertion of the PT and the LCL in 10 cadavers, ${ }^{12}$ and this parameter is currently considered the gold standard in cases of anatomical reconstruction of the PLC. However, knee dimensions vary significantly according to ethnicity and biotype, and, for example, the knees of North American and Caucasian populations are generally larger. ${ }^{13-16}$ Thus, using a distance of $18.5 \mathrm{~mm}$ between the femoral insertions of the PT and the LCL may not be adequate for anatomical reconstruction of the PLC in smaller knees. Constructing tunnels that are very close to each other, i.e., with less than $2 \mathrm{~mm}$ of bone bridge, to reproduce the exact anatomical origins of the LCL and PT, can lead to surgical complications such as tunnel confluence, graft fixation failure, and subsequent instability and failed ligament reconstruction, ${ }^{17,18}$ especially when multiple femoral tunnels are used in cases of multiligament lesions.

Thus, the primary objective of this study is to analyse the distances between the femoral insertions of the PT and the LCL through dissections of cadaveric specimens in a mixed non-Caucasian population to assess whether the distances are comparable to findings in the literature.

\section{MATERIALS AND METHODS}

Fresh unpaired cadavers from our institution were dissected. Approval was obtained from the institutional scientific committee and the Ethics Committee for the Analysis of Hospital Research Projects. Anatomic dissections were performed according to the availability of cadavers from January to May 2019. All specimens had information on age, weight, and height.

The exclusion criteria for anatomical evaluation were cadavers with total knee arthroplasty, fractures of the distal third of the femur, anterior peripheral lateral ligament reconstruction, and a history of joint infection. The distance between the midpoints of the PT and LCL origins in the lateral region of the femoral condyle was measured using a digital calliper (150 mm DC-60 Western, Zhejiang, China) with a precision of $0.01 \mathrm{~mm}$. (Figure 1) For these structures, measurements of the edge points most distant from each other and those closest to each other and the diameters at the largest axis of the femoral insertions of the PT and LCL were also performed.
Anatomical dissections were performed in planes starting with the skin and subcutaneous tissue, followed by tenotomy of the quadriceps tendon in the myotendinous junction. Then, medial parapatellar access was established to open the retinaculum and resect the insertion of the patellar ligament in the anterior tuberosity of the tibia by detaching soft tissues or osteotomy of a small bone fragment. The posterior portion of the retropatellar fat was removed for better visualization of the region. The iliotibial tract was detached from Gerdy's tubercle, and tenotomy of the biceps tendon and detachment of the lateral gastrocnemius were performed. The PT and LCL were carefully dissected and isolated, and the distances from the midpoints, the proximal edges, and the most distal edges to the femoral origins of these two structures, were measured with the knee in $90^{\circ}$ flexion. The measurements were performed by two examiners after dissection of the specimens, and correlation tests were performed between the examiners. Inter-rater reliability was assessed using Cohen's kappa coefficient. The level of agreement was classified according to McHugh: none (0-.20), minimal (.21-.39), weak (.40-.59), moderate (.60-.79), strong (.80-.90), and almost perfect $(>.9) .{ }^{19}$

\section{RESULTS}

In total, 11 knees from eight men and three women with an average age of $71.5 \pm 15.2$ years, an average weight of $57.2 \pm 15.6 \mathrm{~kg}$, and a mean height of $170.5 \pm 8.2 \mathrm{~cm}$ were dissected.

The distance between the midpoints of the femoral origins of the $L C L$ and PT was $10.0 \pm 2.4 \mathrm{~mm}$. The distances between the edges closest to each other and those more distant from each other were $3.1 \pm 1.1 \mathrm{~mm}$ and $16.3 \pm 2.4 \mathrm{~mm}$, respectively. The mean maximum diameter of the PT was $7.9 \pm 2.1 \mathrm{~mm}$, and the mean maximum diameter of the LCL was $7.3 \pm 2.1 \mathrm{~mm}$ (Table 1 and Figure 1).

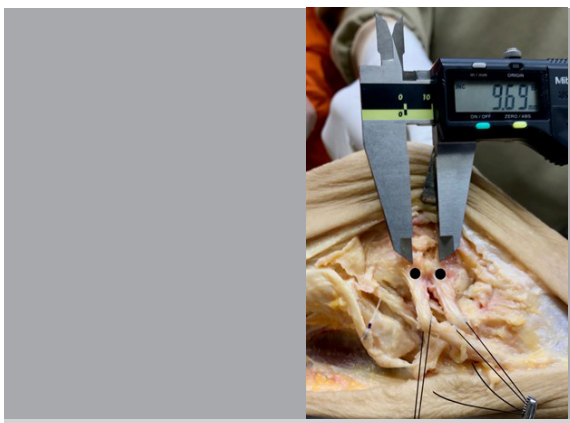

Figure 1. Dissection of the posterolateral complex and identification of the LCL and PT.

Table 1. Dissected specimens

\begin{tabular}{c|c|c|c|c|c|c|c|c|c}
\hline & & & & & \multicolumn{3}{|c|}{ Distances (mm) } & \multicolumn{2}{c}{ Femoral insertion (mm) } \\
\hline Specimens & Gender & Age & Weight (kg) & Height (cm) & Closest edges & Midpoints & Distant edges & Popliteus & LCL \\
\hline 1 & Male & 84 & 50.0 & 162.0 & 4.22 & 9.69 & 14.81 & 5.00 & 4.87 \\
\hline 2 & Male & 91 & 64.0 & 162.0 & 4.50 & 12.71 & 19.08 & 6.96 & 5.14 \\
\hline 3 & Male & 76 & 60.0 & 170.0 & 4.08 & 8.30 & 13.72 & 7.22 & 5.72 \\
\hline 4 & Male & 74 & 98.0 & 181.0 & 3.10 & 11.54 & 18.84 & 12.07 & 8.04 \\
\hline 5 & Female & 84 & 40.0 & 165.0 & 4.30 & 15.28 & 19.25 & 7.77 & 11.98 \\
\hline 6 & Male & 61 & 45.0 & 169.0 & 1.54 & 7.61 & 13.30 & 7.09 & 6.12 \\
\hline 7 & Female & 85 & 55.0 & 160.0 & 1.85 & 7.83 & 12.58 & 5.40 & 6.88 \\
\hline 8 & Female & 43 & 55.0 & 175.0 & 3.33 & 7.82 & 17.43 & 10.40 & 8.40 \\
\hline 9 & Male & 50 & 45.4 & 177.0 & 1.78 & 10.71 & 16.93 & 9.19 & 8.97 \\
\hline 10 & Male & 71 & 64.0 & 185.0 & 2.39 & 10.00 & 17.59 & 7.12 & 5.91 \\
\hline 11 & Male & 67 & 53.0 & 170.0 & 2.16 & 8.83 & 16.71 & 9.26 & 8.84 \\
\hline Average & & $\mathbf{7 1 . 5}$ & $\mathbf{5 7 . 2}$ & $\mathbf{1 7 0 . 5}$ & $\mathbf{3 . 1 1}$ & $\mathbf{1 0 . 0 3}$ & $\mathbf{1 6 . 3 9}$ & $\mathbf{7 . 9 5}$ & $\mathbf{7 . 3 5}$ \\
\hline SD & & $\mathbf{1 5 . 2}$ & $\mathbf{1 5 . 6}$ & $\mathbf{8 . 2}$ & $\mathbf{1 . 1 3}$ & $\mathbf{2 . 4 0}$ & $\mathbf{2 . 4 1}$ & $\mathbf{2 . 1 1}$ & $\mathbf{2 . 1 3}$ \\
\hline
\end{tabular}

The agreement between the examiners was considered strong (kappa $0.86 ; p<.001$ ) 


\section{DISCUSSION}

The main finding of this study is that the distance between the midpoints of the PT and the LCL was shorter than the distances frequently reported in the literature. The value of $10.0 \pm 2.4 \mathrm{~mm}$ is significantly shorter than the previously published distance of $18.5 \mathrm{~mm}$ in another dissection series. ${ }^{12}$ This finding is very interesting because a surgical technique involving tunnels separated by a distance of $18.5 \mathrm{~mm}$ for the LCL and PT does not, necessarily, reproduce more accurately the anatomy of individuals of any population.

The distances and absolute sizes of the knee ligament structures, such as the anterior cruciate ligament, have been directly correlated with the sizes of the lateral femoral wall in the intercondylar notch, the tibial plateau, and femoral and tibial lengths. ${ }^{20,21}$ Our study population had an average height of $170.5 \pm 8.2 \mathrm{~cm}$, which is comparable to the mean heights of populations in South America and several countries worldwide. Notably, the mean population height varies significantly among countries and can reach values greater than $180 \mathrm{~cm}$ for men in European countries such as the Netherlands and approximately $155 \mathrm{~cm}$ for women in India. ${ }^{22}$ The mean height of the population in our study, which is more mixed, may not be similar to the mean height of Caucasian individuals in other studies evaluating posterolateral complex, who tend to be taller. Unfortunately, information regarding the heights of dissected specimens was not reported in other studies, thus complicating comparisons.

Anatomical differences in the knee between different populations have been demonstrated for unicompartmental prostheses. In an anthropometric study of the medial tibial plateau, Surendran et al. ${ }^{23}$ showed that the design of unicondylar arthroplasty developed for Caucasians would be inadequate for the Korean population. Similar studies have been published for Chinese and Turkish populations reinforcing the significance of ethnic anatomical differences. ${ }^{24,25}$

The influence of age on the sizes of anatomical structures is also controversial. Although ligaments and tendons naturally degenerate with age, the sizes of these structures seem to be related to individual bone morphology dimensions. Iriuchishima et al. ${ }^{26}$ evaluated the effect of age on the cross-sectional area of the anterior cruciate ligament in the axial and sagittal planes, and did not find a significant difference when the values were normalized to the length of the Blumensaat line. The specimens in our study were aged $71.5 \pm 15.2$ years and were part of the regional mortality information system, with deaths resulting from natural causes. To our knowledge, no studies have demonstrated that old age can modify, increase, or reduce the footprints of the structures studied.

Moreover, the distance of $10.0 \pm 2.4 \mathrm{~mm}$ between the midpoints of the LCL and PT and its impact on the risk of tunnel confluence must be emphasized when performing ligament reconstruction. In our study, the PT and LCL had mean diameters of $7.9 \mathrm{~mm}$ and $7.3 \mathrm{~mm}$, respectively, at their femoral insertions. For ligament reconstruction with the use of two separate grafts measuring approximately $8 \mathrm{~mm}$, two separate $8-\mathrm{mm}$ tunnels would need to be created for these grafts. In a knee with a $10 \mathrm{~mm}$ distance between the LCL and PT insertions, we would need a bone wall of only $2 \mathrm{~mm}$ between the tunnels, increasing the risk of confluence, which is a worrisome complication in these cases. (Figure 2) Furthermore, in our study, the distance between the midpoints of these footprints was shorter than $10 \mathrm{~mm}$ in six (54.5\%) knees, which would result in tunnel confluence if we used this value for the tunnel diameters.

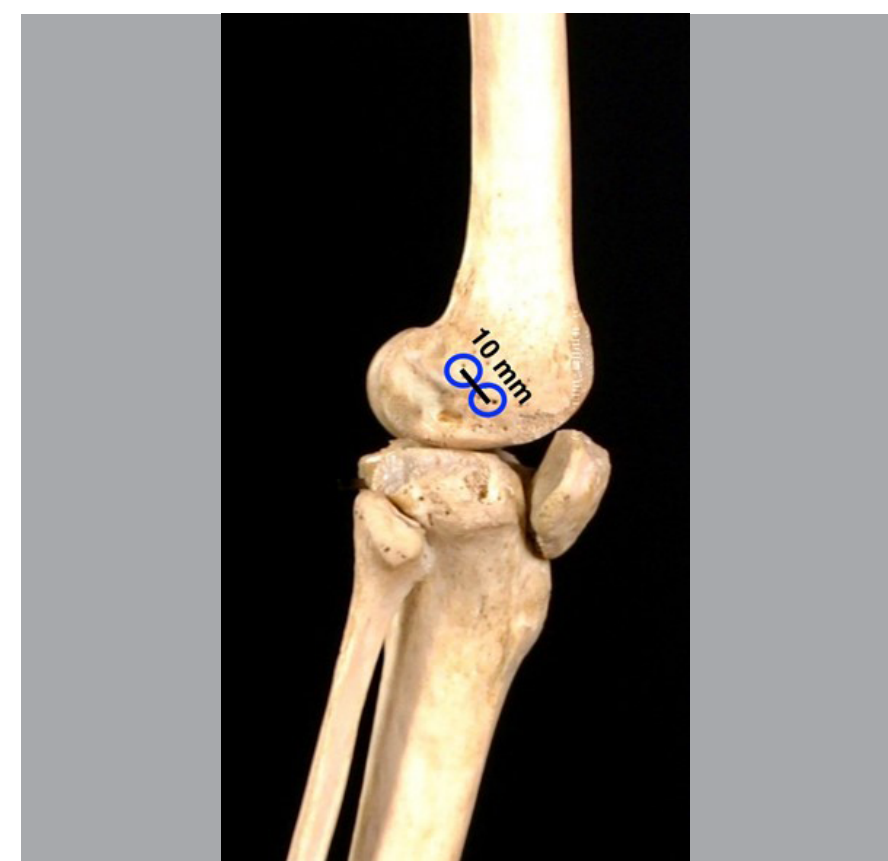

Figure 2. Ligament reconstruction with the use of two separate grafts for the LCL and PT.

The risk of injury to other structures during tunnel creation in the lateral cortical surface of the femur is a complication described by Helito et al. for the anterolateral ligament (ALL). The risk of iatrogenic LCL injury due to an ALL tunnel with a 10-mm diameter can reach $40 \% .{ }^{27}$ In addition to the risk of confluence of the PT and LCL tunnels during ligament reconstruction, when we increase the distance between the tunnels to maintain an adequate bone bridge, we incur the risk of injury to other structures such as the ALL.

A common situation that increases technical and surgical difficulty is ACL injury associated with the posterolateral corner. In this situation, three tunnels in the lateral femoral condyle are required for the LCL, PT, and ACL, increasing the risk of local complications. An alternative strategy to avoid this type of problem would be the use of a single-tunnel technique for the PT and LCL as described by Angelini et al., who reported good clinical results. ${ }^{10,11}$ For this technique, with the knee flexed, the authors recommend positioning the graft of the PT at the most anterior wall inside the femoral tunnel and the LCL graft in most posterior wall. Then, an interference screw is placed between the two tendons to reproduce the anatomical positions of these two structures.

The excellent work reported by LaPrade et al. showed the anatomy of the PLC of the knee in detail and provided a deep understanding of the spatial relationships among the structures of this region, allowing more precise development of surgical techniques considered more consistent with the knee anatomy and emphasizing the importance of reconstruction of the LCL, PT, and popliteofibular ligament. Notably, however, significant differences exist among populations from different countries. Studies comparing miscegenation in South American countries and the United States have reported a miscegenation rate of up to $50 \%$ for Brazil and values lower than $20 \%$ for North America. In China, these values are less than 5\%. ${ }^{28,29}$

Therefore, the results in our study do not necessarily contradict those of previous studies; however, they suggest that regional differences may exist between populations, reinforcing the importance of an individualized evaluation for the treatment of each patient. 


\section{CONCLUSION}

The distance between the midpoints of the PT and LCL showed a lower absolute value than the distances often reported in the literature. The value of $10.0 \pm 2.4 \mathrm{~mm}$ is significantly lower than previously published values. Ligament reconstruction with separate tunnels for the LCL and PT may not be technically possible for individuals of any population.

AUTHORS' CONTRIBURTIONS: Each author contributed individually and significantly to the development of this article. MFS: article writing and review, surgeries; CPH: article writing and review, and study concept; LPM: article writing and review, surgeries; AMA: statisticla analysis, surgeries and article review; RGG: article writing and review, and study concept; FJA: article writing and review, and study concept.

\section{REFERENCES}

1. LaPrade RF, Wentorf FA, Fritts H, Gundry C, Hightower CD. A prospective magnetic resonance imaging study of the incidence of posterolateral and multiple ligament injuries in acute knee injuries presenting with a hemarthrosis. Arthroscopy. 2007;23(12):1341-7.

2. LaPrade RF, Resig S, Wentorf F, Lewis JL. The effects of grade III posterolateral knee complex injuries on anterior cruciate ligament graft force. A biomechanical analysis. Am J Sports Med. 1999;27(4):469-75.

3. Noyes FR, Barber-Westin SD. Posterior cruciate ligament revision reconstruction part 1: causes of surgical failure in 52 consecutive operations. Am J Sports Med. 2005;33(5):646-54.

4. Chahla J, Moatshe G, Dean CS, LaPrade RF. Posterolateral corner of the knee: current concepts. Arch Bone Jt Surg. 2016;4(2):97-103.

5. Geeslin AG, Moulton SG, LaPrade RF. A systematic review of the outcomes of posterolateral corner knee injuries, part 1: surgical treatment of acute injuries. Am J Sports Med. 2016;44(5):1336-42.

6. Moulton SG, Geeslin AG, LaPrade RF. A systematic review of the outcomes of posterolateral corner knee injuries, part 2: surgical treatment of chronic injuries. Am J Sports Med. 2016;44(6):1616-23.

7. LaPrade RF, Johansen S, Wentorf FA, Engebretsen L, Esterberg JL, Tso A. An analysis of an anatomical posterolateral knee reconstruction: an in vitro biomechanical study and development of a surgical technique. Am J Sports Med. 2004;32(6):1405-14.

8. Veltri DM, Deng XH, Torzilli PA, Maynard MJ, Warren RF. The role of the popliteofibular ligament in stability of the human knee. A biomechanical study. Am J Sports Med. 1996;24(1):19-27.

9. Helito CP, Bonadio MB, Demange MK, da Mota e Albuquerque RF, Pécora JR, Camanho GL, Angelini FJ. Functional assessment of combined reconstruction of the anterior cruciate ligament and posterolateral corner with a single femoral tunnel: a two-year minimum follow-up. Int Orthop. 2015;39(3):543-8.

10. Angelini FJ, Helito CP, Tozi MR, Pozzobon L, Bonadio MB, Gobbi RG, et al. Combined reconstruction of the anterior cruciate ligament and posterolateral corner with a single femoral tunnel. Arthrosc Tech. 2013;2(3):e285-8.

11. Helito CP, Sobrado MF, Giglio PN, Bonadio MB, Pécora JR, Gobbi RG, et al. Clinical Outcomes of Posterolateral Complex Reconstruction Performed with a Single Femoral Tunnel. J Knee Surg. 2019;34(1):67-73.

12. LaPrade RF, Ly TV, Wentorf FA, Engebretsen L. The posterolateral attachments of the knee: a qualitative and quantitative morphologic analysis of the fibular collateral ligament, popliteus tendon, popliteofibular ligament, and lateral gastrocnemius tendon. Am J Sports Med. 2003;31(6):854-60.

13. Urabe K, Mahoney OM, Mabuchi K, Itoman M. Morphologic differences of the distal femur between Caucasian and Japanese women. J Orthop Surg (Hong Kong). 2008;16(3):312-5.

14. Kim TK, Phillips M, Bhandari M, Watson J, Malhotra R. What differences in morphologic features of the knee exist among patients of various races? A systematic review. Clin Orthop Relat Res. 2017;475(1):170-82.

15. Yue B, Varadarajan KM, Ai S, Tang T, Rubash HE, Li G. Differences of knee anthropometry between Chinese and white men and women. J Arthroplasty. 2011;26(1):124-30.

16. Vaidya SV, Ranawat CS, Aroojis A, Laud NS. Anthropometric measurements to design total knee prostheses for the Indian population. J Arthroplasty. 2000;15(1):79-85.

17. Hantes ME, Liantsis AK, Basdekis GK, Karantanas AH, Christel P, Malizos KN. Evaluation of the bone bridge between the bone tunnels after anatomic double-bundle anterior cruciate ligament reconstruction: a multidetector computed tomography study. Am J Sports Med. 2010;38(8):1618-25.

18. Lee SH, Choi JY, Kim DH, Kang BJ, Nam DC, Yoon HK, Hwang SC. Correlation between femoral guidewire position and tunnel communication in double bundle anterior cruciate ligament reconstruction. Yonsei Med J. 2014;55(6):1592-9.

19. McHugh ML. Interrater reliability: the kappa statistic. Biochem Med (Zagreb). 2012;22(3):276-82.

20. Iriuchishima T, Shirakura K, Yorifuji H, Aizawa S, Murakami T, Fu FH. ACL footprint size is correlated with the height and area of the lateral wall of femora intercondylar notch. Knee Surg Sports Traumatol Arthrosc. 2013;21:789-96.

21. Iriuchishima T, Ryu K, Aizawa S, Fu FH. Proportional evaluation of anterior cruciate ligament footprint size and knee bony morphology. Knee Surg Sports Traumatol Arthrosc. 2015;23(11):3157-62.

22. Perkins JM, Subramanian SV, Davey Smith G, Özaltin E. Adult height, nutrition, and population health. Nutr Rev. 2016;74(3):149-65.

23. Surendran S, Kwak DS, Lee UY, Park SE, Gopinathan P, Han SH, Han CW. Anthropometry of the medial tibial condyle to design the tibial component for unicondylar knee arthroplasty for the Korean population. Knee Surg Sports Traumatol Arthrosc. 2007;15(4):436-42.

24. Cheng FB, Ji XF, Zheng WX, Lai Y, Cheng KL, Feng JC, Li YQ. Use of anthropometric data from the medial tibial and femoral condyles to design unicondylar knee prostheses in the Chinese population. Knee Surg Sports Traumatol Arthrosc. 2010;18(3): 352-8.

25. Küçükdurmaz F, Tuncay I, Elmadağ M, Tunçer N. Morphometry of the medial tibial plateau in Turkish knees: correlation to the current tibial components of unicompartmental knee arthroplasty. Acta Orthop Traumatol Turc. 2014;48(2):147-51.

26. Iriuchishima T, Ryu K, Fu FH. Evaluation of age-related differences in anterior cruciate ligament size. Knee Surg Sports Traumatol Arthrosc. 2019;27(1):223-9.

27. Helito CP, Bonadio MB, Gobbi RG, da Mota E Albuquerque RF, Pécora JR, Camanho GL, Demange MK. Is it safe to reconstruct the knee anterolateral ligament with a femoral tunnel? Frequency of lateral collateral ligament and popliteus tendon injury. Int Orthop. 2016;40(4):821-5.

28. Travassos C, Williams DR. The concept and measurement of race and their relationship to public health: a review focused on Brazil and the United States. Cad Saude Publica. 2004;20(3):660-78.

29. Zhu Z, editor. The People's Republic of China Today: Internal and External Challenges. Singapore: World Scientific; 2011. 